Original article (short paper)

\title{
Neural and morphological adaptations of vastus lateralis and vastus medialis muscles to isokinetic eccentric training
}

\author{
Rodrigo de Azevedo Franke \\ Federal University of Rio Grande do Sul, Porto Alegre, Brazil \\ Bruno Manfredini Baroni \\ Federal University of Health Sciences of Porto Alegre, Brazil \\ Rodrigo Rodrigues \\ Federal University of Rio Grande do Sul, Porto Alegre, Brazil \\ Jeam Marcel Geremia \\ Faculty of Physical Education Sogipa, Porto Alegre, Brazil \\ Fábio Juner Lanferdini \\ Marco Aurélio Vaz \\ Federal University of Rio Grande do Sul, Porto Alegre, Brazil
}

\begin{abstract}
Vastus lateralis (VL) and vastus medialis (VM) are frequently targeted in conditioning/rehabilitation programs due to their role in patellar stabilization during knee extension. This study assessed neural and muscular adaptations in these two muscles after an isokinetic eccentric training program. Twenty healthy men underwent a four-week control period followed by a 12-week period of isokinetic eccentric training. Ultrasound evaluations of VL and VM muscle thickness at rest and electromyographic evaluations during maximal isometric tests were used to assess the morphological and neural properties, respectively. No morphological and neural changes were found throughout the control period, whereas both muscles showed significant increases in thickness $(\mathrm{VL}=6.9 \% ; p<.001$ and $\mathrm{VM}=15.8 \% ; p<.001)$ posttraining. Significant increases in muscle activity were observed in VM $(47.8 \% ; p=.003)$, but not in VL $(19.8 \% ; p>$ $.05)$ post-training. Isokinetic eccentric training produces neural and greater morphological adaptations in VM compared to VL, which shows that synergistic muscles respond differently to an eccentric isokinetic strength training program.
\end{abstract}

Keywords: knee extensors, isokinetic dynamometry, ultrasonography, electromyography

Resumo - "Adaptações neurais e morfológicas dos músculos vasto lateral e vasto medial para treinamento isocinético excêntrico." Vasto lateral (VL) e vasto medial (VM) são comumente visados em programas de condicionamento/reabilitação devido ao seu papel na estabilização patelar durante a extensão do joelho. Este estudo avaliou as adaptações neurais e musculares nesses dois músculos após um programa de treinamento excêntrico em dinamômetro isocinético. Vinte homens saudáveis foram submetidos a um período controle de quatro semanas seguido de um período de 12 semanas de treinamento excêntrico isocinético. Avaliações de ultrassom da espessura muscular do VL e VM em repouso e avaliações eletromiográficas durante testes isométricos máximos foram utilizadas para acessar as propriedades morfológicas e neurais, respectivamente. Não foram encontradas diferenças significativas no período controle para adaptações morfológicas e neurais, enquanto ambos os músculos mostraram incrementos significativos ( $\mathrm{VL}=6,9 \% ; p<0,001 \mathrm{e} \mathrm{VM}=15,8 \% ; p<0,001)$ no pós-treino. Incrementos significativos na atividade muscular foram observados no $\operatorname{VM}(47,8 \% ; p=0,003)$, mas não no $\operatorname{VL}(19,8 \% ; p>0,05)$ no pós-treino. O treinamento excêntrico isocinético produziu adaptações neurais e maiores adaptações morfológicas no VM comparado ao VL, o que mostra que músculos sinergistas respondem de foram distinta a um programa de treinamento de força isocinético excêntrico.

Palavras-chave: extensores do joelho, dinamometria isocinética, ultrassonografia, eletromiografia

Resumen - "Adaptaciones neurales y morfológicas de los músculos vasto externo y vasto medial a entrenamiento isocinético excéntrico." Vasto lateral (VL) y vasto medial (VM) son señalados en los programas de acondicionamiento/rehabilitación debido a su papel en la estabilización de la rótula durante la extensión de la rodilla. Este estudio evaluó adaptaciones neurales y musculares en estos dos músculos después de un programa de entrenamiento excéntrico isocinético. Veinte hombres saludables 
fueron sometidos a un período de control de cuatro semanas, seguido de un período de 12 semanas de entrenamiento excéntrico isocinético. Se han usado las evaluaciones de ultrasonido de la espesor del músculo VL y VM en reposo y las evaluaciones electromiográficas durante las pruebas isométricas máximas para evaluar las propiedades morfológicas y neurales, respectivamente. No se observaron diferencias morfológicos y neurales significativas a lo del período de control, mientras que los dos músculos mostraron incrementos significativos en la espesor del músculo ( $\mathrm{VL}=6,9 \%, p<0,001$ y VM $=15,8 \%, p<0,001)$ después de lo entrenamiento. Aumentos significativos en la actividad muscular se observaron en VM $(47,8 \%, p=0,003)$, pero no en VL $(19,8 \%, p>0,05)$ después de lo entrenamiento. Entrenamiento excéntrico isocinético produce adaptaciones neurales y mayores adaptaciones morfológicas en VM en comparación con VL, lo que demuestra que los músculos sinérgicos responden de manera diferente a un programa de entrenamiento de fuerza isocinético excéntrico.

Palabras clave: extensores de la rodilla, dinamometría isocinética, ecografía, electromiografía

\section{Introduction}

The knee extensor muscle group [i.e., rectus femoris (RF), vastus lateralis (VL), vastus medialis (VM) and vastus intermedius (VI)] is primarily responsible for the dynamic stabilization of the patellofemoral joint (Serrão, Cabral, Bérzin, Candolo, \& Monteiro-Pedro, 2012). The strength unbalance between VM and VL is a key mechanism for knee dysfunctions, such as patellofemoral pain syndrome (LaBella, 2004; Wong, Chan, Tang, \& Ng, 2009; Wong \& Ng, 2010). Patellofemoral instability is often associated with VM weakness and patellar lateralization (Neptune, Wright \& Van Den Bogert, 2000; Powers, Landel \& Perry, 1996; Sheehy, Burdett, VanSwearing \& Irrgang, 1998). Previous studies, interested in conditioning/rehabilitation programs for the (re)balance between VM and VL, have evaluated knee extension exercises that were assumed to promote a predominant action of the VM muscle (Cerny, 1995; Kushion et al., 2012; Matheson, Kernozek, Fater, \& Davies, 2001; Mirzabeigi, Jordan, Gronley, Rockowitz, \& Perry 1999; Peng \& Kernozek Song, 2013). However, most of them have failed to show a different behavior between these two synergistic muscles during specific exercises and, to date, there is no consensus regarding a gold standard method to emphasize VM or VL muscle activity.

Despite this lack of consensus, patients with patellofemoral pain syndrome have engaged in resistance training rehabilitation programs for knee extensors strengthening (American College of Sports Medicine, 2009). Although the conventional resistance training involves exercises with both concentric and eccentric muscle actions, eccentric training has become popular in recent decades for conditioning and rehabilitation purposes (Barstow, Bishop, \& Kaminski, 2003; Lorenz \& Reiman, 2011; Vikne et al., 2006; Visnes \& Bahr, 2007), and the effects of eccentric training programs on knee extensor muscles have been reported for healthy adults (Rocha et al., 2011), elderly (Reeves, Maganaris, Longo, \& Narici, 2009), patients with patellar tendinopathy (Jonsson \& Alfredson, 2005), anterior cruciate ligament reconstruction (Gerber et al., 2009) and patellofemoral pain syndrome (Eapen, Nayak, \& Pazhyaottyil Zulfeequer, 2011).

Although eccentric training leads to significant muscle strength gains (Roig et al., 2009), a direct measure of the strength gain from each portion of the knee extensor muscle group cannot be obtained. We have recently demonstrated (Baroni et al., 2013a) that the time course of neuromuscular adaptations to isokinetic eccentric training is similar to that previously reported for conventional resistance training programs (Folland \& Williams, 2007;
Guilhem, Cornu, \& Guével, 2010; Guilhem, Cornu, Maffiuletti, \& Guével, 2013; Moritani \& deVries, 1979; Narici et al., 1996; Narici, Roi, Landoni, Minetti, \& Cerretelli, 1989; Wernbom, Augustsson, \& Thomee, 2007). More specifically, strength gains are predominantly associated with neural adaptations (i.e., increased muscle activity) in the first weeks of a training program, while morphological adaptations (i.e., increased muscle mass) affects strength capacity in a later stage of training. However, it is not clear how these two different adaptations affect synergistic muscles or if the amount of neural and morphological adaptations is similar between VL and VM during eccentric isokinetic training. Thus, verifying the neural and morphological changes of each knee extensor muscle in response to an isokinetic eccentric training program may help us to better understand neuromuscular plasticity in these synergistic muscles, since non-uniform adaptations are reported on literature, especially to eccentric exercise, which could lead to non-uniform activation, alternative muscle synergies and strength imbalances (Hedayatpour \& Falla, 2012).

Most studies on knee extensor eccentric training accessed only the VL muscle and extrapolated its responses to the whole knee extensor muscle group in terms of neural (Hortobagyi et al., 1996a) and morphological adaptations (Raj, Bird, Westfold, \& Shield, 2012; Reeves et al., 2009). However, many researchers and clinicians are interested on the specific responses of each patellar dynamic stabilizer throughout an eccentric training program, which was assessed for a few clinical trials that provided inconsistent results (Baroni et al., 2013b; Blazevich, Cannavan, Coleman, \& Horne, 2007; Blazevich, Horne, Cannavan, Coleman \& Aagaard, 2008; Hortobagyi et al., 1996b). In this context, the aim of this study was to evaluate the neural and morphological responses of the VL and VM muscles after 12 weeks of knee extensor isokinetic eccentric training.

\section{Methods}

\section{Study's design}

This longitudinal clinical trial was designed to assess the neural and morphological adaptations of VL and VM muscles in response to a knee extensor isokinetic eccentric training program. The study was approved by the institutional ethics in research committee of the Federal University of Rio Grande do Sul, Porto Alegre, Brazil (protocol 20485).

Volunteers were evaluated three times over a period of sixteen weeks (Figure 1) to assess the VL and VM morphology by ultrasonographic images at rest. Surface electromyographical 


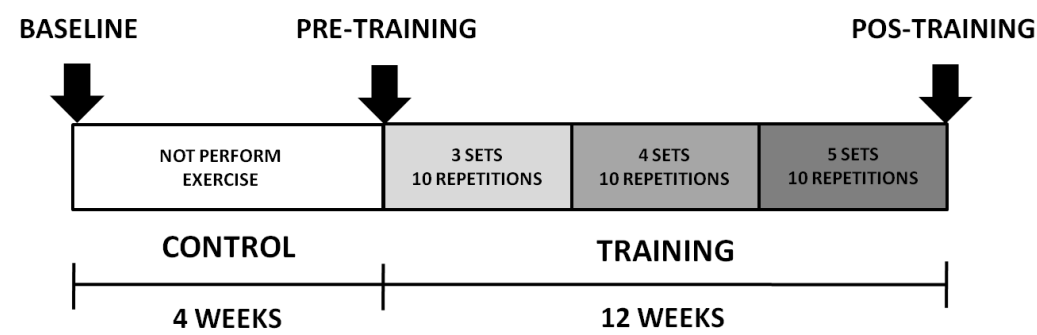

Figure 1. Experimental design of the study: a control period during four weeks; a 12-week isokinetic eccentric training period; and three evaluation sessions (indicated by the arrows) throughout the study.

activity was recorded from VL and VM during maximal isometric voluntary contraction through an electromyography (EMG) apparatus. After the first evaluation (Baseline), volunteers were subjected to a non-training period, in which they were instructed to not perform any systematic exercise during four weeks. After the control period, they were submitted to a second evaluation (pre-training). This experimental design discarded the necessity of a non-trained control group, since all volunteers underwent the same control period immediately before the isokinetic eccentric training program. After the second evaluation, volunteers initiated a 12-week isokinetic eccentric training program performed on an isokinetic dynamometer. The last evaluation was performed after the $12^{\text {th }}$ week of training (post-Training).

\section{Volunteers}

Male students, aged 20 to 35 years, were invited to participate in the study. All were physically active healthy subjects uninvolved in any kind of systematized lower-limb resistance training program for at least six months prior to the experiment. Volunteers were informed about all the study procedures and were selected to participate considering the following exclusion criteria: history of lower-limb musculoskeletal disorders that could limit volunteers' performance during training and tests; respiratory or cardiovascular diseases; use of nutritional supplements or anabolic steroids.

\section{Muscle thickness assessment}

A B-mode ultrasound system (Aloka SSD-4000, Aloka Inc., Japan), with a linear-array probe $(60 \mathrm{~mm}, 7.5 \mathrm{MHz})$ of the same manufacturer, was used to determine the VL and VM muscle thickness. Maps of the thigh morphology were made using malleable plastic sheets in which anatomical reference points (i.e., border of patella), skin marks (i.e., scars and freckles) and the ultrasonography scanning sites were marked to ensure that repetitive evaluation scans were taken from the same anatomical site. All the ultrasonography data collection and data analysis procedures were made based on previous studies from our group (Baroni et al., 2013a; Baroni et al., 2013b).

Volunteers were evaluated by the same investigator with large experience in ultrasonographic measurements, and were instructed to not execute any vigorous physical activity 48 hours before the evaluations. On a supine position, with the knee fully extended, muscles relaxed and after 10 minutes of rest, scans were taken in the midway between the greater trochanter and the lateral femur condyle for VL; and at a point 25-30\% (according participant's characteristics) on the line from the anterior superior iliac spine to the medial femur condyle for VM (Baroni et al., 2013a; Baroni et al., 2013b; Blazevich et al., 2007). The ultrasonography probe was covered with a water-soluble transmission gel and oriented parallel to the muscle fascicles and perpendicular to the skin over VL and VM.

Three ultrasonographic images were taken in each site and muscle thickness from VL and VM was analyzed by the same investigator through the Image-J software (National Institute of Health, Bethesda, Maryland, USA). The distance between the deep and the superficial aponeuroses of the target muscle was measured at five different points in each ultrasound image, and a mean value was used as the mean thickness of that ultrasound image. Mean values were obtained from three ultrasound images and taken as the muscle thickness for each target muscle. When dispersion between the three values was higher than $10 \%$, the more discrepant value was excluded and only the two closest ones were considered for analysis. Images of the VL and VM muscles from a representative participant are presented in Figure 2.

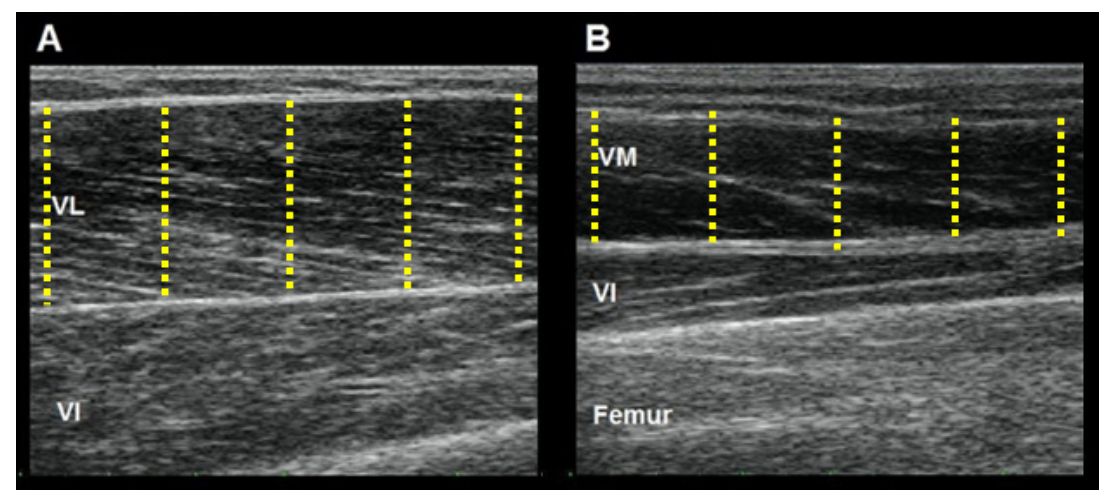

Figure 2. Ultrasonography images of vastus lateralis (A) and vastus medialis (B) from a representative participant. The vertical dashed lines represent the five measures of the target muscle thickness in each image. VM=vastus medialis; VL=vastus medialis; VI = vastus intermedius. 


\section{Muscle activity assessment}

An eight-channel EMG system (AMT-8, Bortec Biomedical Ltd., Canada) connected to a Windaq data acquisition system (Dataq Instruments Inc., USA) was synchronized with the dynamometer and used to evaluate the electrical activity of the VL and VM muscles during maximal isometric voluntary contractions (MIVC). Three MVIC were performed at $60^{\circ}$ of knee flexion $\left(0^{\circ}\right.$ knee fully extended) and each one lasted $5 \mathrm{~s}$. Volunteers were sat and fixed with straps on the dynamometer chair in order to avoid body movements and compensations that could change the torque being produced during knee extension and were verbally encourage to ensure maximal force production (McNair, Depledge, Brettkelly, \& Stanley, 1996). EMG electrodes were placed longitudinally with respect to the underlying muscle fiber arrangement and located according to the Surface Electromyography for the Non-Invasive Assessment of Muscles (SENIAM, 2013). Passive electrodes (Meditrace 100, Kendall, USA) with $15 \mathrm{~mm}$ radius and $20 \mathrm{~mm}$ of centre-to-centre distance were attached to the skin in bipolar configuration on the VL (2/3 on the line from the anterior superior iliac spine to the superior part of the patella) and VM ( $80 \%$ on the line from the anterior superior iliac spine to the joint space in front of the anterior border of the medial collateral ligament). As in ultrasonography procedures, maps were made using malleable plastic sheets and the same reference points were used to ensure the same electrodes positioning in all electromyographic evaluations.

Raw EMG signals were digitized with a sampling frequency of $2000 \mathrm{~Hz}$ with a 16 bits analogue-to-digital board (DI-720, Dataq Instruments Inc., USA) and stored for further analysis. Data were exported to SAD32 software and, after gain compensation and off-set correction, a band-pass digital filter $\left(5^{\text {th }}\right.$ order Butterworth with cut-off frequencies of 20-500 $\mathrm{Hz}$ ) was applied to the EMG signals. One-second segments of the EMG signals from each muscle were selected from a steady-state region (when torque was maximal and constant) of the force signal of the MIVCs to calculate the root mean square (RMS) values.

\section{Isokinetic eccentric training}

The eccentric training program was performed on the same isokinetic dynamometer used for evaluations. In order to respect the progression principle, training volume (number of sets $\mathrm{x}$ number of repetitions per set in each session) was increased in each mesocycle (Figure 1). Training sessions were performed twice a week, with a minimum interval of $72 \mathrm{~h}$ between sessions. Participants performed only one training session in the first training week to allow for progressive introduction to the training regimen, as well as in the $5^{\text {th }}$ and $9^{\text {th }}$ training weeks, due to the increments in training volume during these weeks. Each training session was comprised of a 5-min warm-up exercise on a cycle-ergometer followed by a 3-5 sets of 10 repetitions with a 1-min rest period between sets.

Volunteers, as in MVIC tests, were sat and fixed on the dynamometer chair in order to avoid compensations. Each eccentric contraction began with a passive extension of the volunteer's limb up to $30^{\circ}$ of knee flexion $\left(0^{\circ}=\right.$ knee fully extended). As soon as the dynamometer arm reached this position, volunteers were verbally encouraged to promote their maximum knee extension contraction. In response, the dynamometer generated a flexion torque, driving the segment to $90^{\circ}$ of knee flexion (range of motion $=60^{\circ}$ ) at an angular velocity of $60^{\circ} . \mathrm{s}^{-1}$. As a result, the eccentric contraction phase and the passive knee extension phase lasted one second each one (Baroni et al., 2010).

This study was conducted with 20 volunteers, 15 left and 5 right legs (or 16 non-dominant and 4 dominant legs). Eighteen volunteers completed the 21 training sessions and 2 participants missed one session each due to personal reasons (adherence: $99.5 \%$ ).

\section{Statistical analysis}

An intraclass correlation coefficient (ICC) was applied to verify the test-retest reliability between baseline and pretraining evaluations for all measurements, and we adopt the classification suggested by Sole, Hamrén, Milosavljevic, Nicholson, and Sullivan (2007), in which correlations of .50 to .69 are "moderate," .70 to .90 are "high," and higher than .90 are "very high." Absolute values of muscle thickness and muscle activity from each muscle (VM and VL) throughout the three time points (baseline, pre-training and post-training) were compared through a repeated measures ANOVA. Mauchly's test was performed and the Greenhouse-Geisser correction factor was applied when the assumption of sphericity was violated. When the time effect was pointed out, a Bonferroni post-hoc test was used to identify the differences between the time points within each muscle. All statistical analyses were performed with an alpha level of $p<.05$. Results are presented in the text and tables as mean \pm standard deviation.

\section{Results}

Twenty volunteers completed the full study schedule. The sample presented a mean of $24.0 \pm 3.7$ years, $175.0 \pm$ $6.0 \mathrm{~cm}$ and $73.9 \pm 6.9 \mathrm{~kg}$. The participants' weight was monitored throughout the full experiment and did not change significantly.

Data obtained in baseline and pre-training evaluations presented high to very high ICC scores for test-retest reliability for muscle thickness $(\mathrm{VL}=.91 ; \mathrm{VM}=.86)$ and muscle activity $(\mathrm{VL}=.86 ; \mathrm{VM}=.79)$ procedures. Furthermore, there was no significant difference $(p>.05)$ in any variable between these 2 time-points (Tables 1 and 2).

When comparing pre-training to post-training values, significant increases were observed in muscle thickness for $\mathrm{VL}(6.9 \%$, $p<.001 ; 0.548 ; 95 \% \mathrm{CI}=2.540-2.771)$ and $\mathrm{VM}(15.8 \%, p$ $<.001 ; 0.570 ; 95 \% \mathrm{CI}=1.845$ - 2.111) (Table 1$)$. There was a significant increase in VM muscle activity $(47.8 \%, p=.003$; $0.457 ; 95 \% \mathrm{CI}=0.189-0.280)$, but not in $\mathrm{VL}(19.8 \%, p>.05$; $0.144 ; 95 \% \mathrm{CI}=0.174-0.263$ ) (Table 2). 
Table 1. Muscle thickness values [in $\mathrm{cm}$; mean \pm standard deviation (coefficient of variation)] from vastus lateralis (VL) and vastus medialis (VM) during the control period and after the 12-week isokinetic eccentric training period.

\begin{tabular}{ccccc}
\hline & Baseline & Pre-training & Post-training & $\boldsymbol{\Delta} \%$ \\
\hline VL & $2.61 \pm 0.24$ & $2.58 \pm 0.23$ & $2.76 \pm 0.29$ & 6.92 \\
& $(0.092)$ & $(0.090)$ & $(0.105) *$ & \\
VM & $1.87 \pm 0.32$ & $1.88 \pm 0.28$ & $2.17 \pm 0.32$ & 15.84 \\
& $(0.172)$ & $(0.153)$ & $(0.147) *$ & \\
\hline
\end{tabular}

* Significant different between pre- and pos-training; $\Delta \%=$ percent change pre- to post-training.

Table 2. Muscle activity values [in $\mathrm{mV}$; mean \pm standard deviation (coefficient of variation)] from vastus lateralis (VL) and vastus medialis (VM) during the control period and after the 12-week isokinetic eccentric training period.

\begin{tabular}{ccccc}
\hline & Baseline & Pre-training & Post-training & $\boldsymbol{\Delta} \%$ \\
\hline VL & $0.20 \pm 0.11$ & $0.20 \pm 0.09$ & $0.24 \pm 0.10$ & 19.82 \\
& $(0.550)$ & $(0.450)$ & $(0.411)$ & \\
VM & $0.19 \pm 0.09$ & $0.20 \pm 0.10$ & $0.30 \pm 0.13$ & 47.75 \\
& $(0.468)$ & $(0.529)$ & $(0.432) *$ & \\
\hline
\end{tabular}

* Significant different between pre- and pos-training; $\Delta \%=$ percent change pre- to post-training.

\section{Discussion}

Our main findings indicated that a knee extensor eccentric training program performed in isokinetic conditions was able to promote significant increases on VL and VM muscles thickness, with more pronounced changes in VM, while improvements on neural activity capacity were found only for VM.

The experimental design used in this study eliminated the need for a non-trained control group, since all volunteers underwent the same four-week control period immediately before the isokinetic eccentric training program. The high ICC scores and the absence of significant differences between baseline and pre-training evaluations confirmed the test-retest reliability of the methodological procedures for muscle thickness and muscle activity, strengthening the results observed after the training period.

Eccentric contraction presents smaller motor unit activation when compared with isometric or concentric contractions (Barroso, Tricoli, \& Ugrinowitsch, 2005; Enoka, 1996), but higher force production. This enhanced tension is mainly attributed to the passive force produced by the elastic components during eccentric muscle actions (Bojsen-Møller, Magnusson, Rasmussen, Kjaer, \& Aagaard, 2005), leading to a high tension developed by each muscle fiber (or specific tension). This specific behavior, in association with the sarcomere length non-uniformity during this type of muscle action (Morgan \& Proske, 2004), causes the phenomenon known as "exercise-induced muscle damage", characterized by ruptures in the microscopic structures of muscle tissue (Clarkson \& Hubal, 2002; Howatson \& Someren, 2008).

Morphological adaptation, such as muscle fibers' hypertrophy, is a key response of the eccentric training programs. The systematic review with meta-analysis developed by Roig et al. (2009) confirmed the superiority of eccentric compared to concentric training in relation to muscle mass gain. In addition, although clinical trials comparing eccentric and conventional resistance training observed no hypertrophic differences after a 14- 16-week training program (Raj et al., 2012; Reeves et al., 2009), morphological responses to eccentric training seems to occur earlier than conventional resistance training responses (Norrbrand, Fluckey, Pozzo, \& Tesch, 2008). These observations have been commonly associated with the higher levels of exercise-induced muscle damage induced by eccentric exercises, since muscle damage is an activation mechanism for the repair process that leads to the addition of sarcomeres aligned in-parallel, characteristic of muscle hypertrophy (Schoenfeld, 2010).

In relation to neural adaptations, most studies suggest that motor unit activation increases in eccentric actions but not in concentric actions after eccentric training programs (Higbie, Cureton, Warren, \& Prior, 1996; Hortobagyi et al., 1996a; Hortobagyi et al., 1996b). Additionally, although neural changes in isometric actions have shown inconsistent results with eccentric training programs (Blazevich et al., 2008; Hortobagyi et al., 1996b), a recent study from our group (Baroni et al., 2013a) demonstrated that isokinetic eccentric training is able to increase knee extensor muscle activity in maximal isometric tests, but in smaller magnitude than observed in maximal eccentric tests. Therefore, although the main observed changes appear to be related to a reduction in muscle inhibition during eccentric contractions due to the training specificity principle, changes in isometric muscle activity are also part of the neural adaptation to isokinetic eccentric training.

In this study, we accessed the hypertrophic response through the muscles' thickness. Both VL and VM showed significant increases in muscle thickness due to the isokinetic eccentric training program. However, the mean relative increase (percentage values) observed for each knee extensor muscle suggest that the intervention had a more pronounced effected in VM compared to VL (15.8\% vs. 6.9\%). This larger VM response is in agreement with results reported by Blazevich et al. (2007), who observed increases of $18 \%$ and $11 \%$ in anatomical cross-sectional area for VM and VL, respectively, after 10 weeks of knee extensor eccentric isokinetic training.

One possible explanation for this greater response of VM compared to that of VL is the higher fast-twitch fibers composition (Travnik, Pernus, \& Erzen, 1995), which are more susceptible to exercise-induced muscle damage (Clarkson \& Hubal, 2002; Fridén \& Lieber, 1998; Takekura, Fujinami, Nishizawa, Kasuga, \& Ogasawara, 2001) due to its low oxidative capacity and great capacity to generate tension (Hedayatpour \& Falla, 2012). Moreover, VM fibers are a little shorter than VL fibers (Ward et al., 2009), which may contribute to a larger stretch of sarcomeres during eccentric knee extensor exercises and, consequently, a possible increased probability of micro ruptures in the VM muscle tissue. Additionally, a greater hypertrophic response in the distal region of quadriceps (where we measured VM) when compared to the central region (where we measured VL) (Hedayatpuor \& Falla, 2012; Narici et al., 1996; Narici et al., 1989; Seynnes, Boer, \& Narici, 2007) could be related to the regional differences in force transmission along the muscle 
length, since muscle fiber forces are not only transmitted longitudinally to the tendinous structures but also laterally through the connective tissue matrix (Seynnes et al., 2007).

Another explanation for the higher hypertrophic response of VM compared to VL may be the different muscle activity levels of these muscles during the isokinetic eccentric training program. However, previous studies assessing the muscle activity of VM and VL during maximal isokinetic eccentric exercises at $60^{\circ} . \mathrm{s}^{-1}$ have presented conflicting results. While data from Sczepanski, Gross, Duncan, and Chandler (1991) suggest a more effective muscle activity of VM compared to VL, findings from Guilhem, Cornu, and Guevel (2011) suggest similar muscle activity levels between these muscles.

Our findings indicate that only VM muscle activity capacity was affected by the isokinetic eccentric training program, disagreeing from findings of previous studies (Blazevich et al., 2008; Hortobagyi et al., 1996b) and suggesting that this portion of the quadriceps femoris was emphasized by eccentric exercises performed on the isokinetic dynamometer, as suggested by Sczepanski et al. (1991). However, in view of these inconsistent findings, it is difficult to attribute the morphological adaptations to a different muscle activity level between VM and VL during maximal isokinetic eccentric contractions.

This study was not able to identify the exact mechanisms behind the greater adaptation of VM compared to VL in relation to neural and morphological factors. However, two main points demonstrated by these results should be highlighted. The first one is that different portions of the quadriceps femoris present specific responses to isokinetic eccentric training. Therefore, we do not recommend the use of VL (or other single part of quadriceps femoris) as a reliable representative of the whole knee extensor muscle group in future studies.

The second, and more important point, is that the eccentric training performed on the isokinetic dynamometer emphasized the adaptations of VM compared to those of VL. Although we were unable to perform direct measures of VM and VL strength capacity, the higher increases in muscle mass and muscle activity observed in the medial portion of the quadriceps femoris suggest that VM strengthening was greater than VL strengthening. Therefore, in a clinical setting where the VM weakness is usually diagnosed as a mechanism for some knee joint dysfunctions, such as patellofemoral pain syndrome, this training intervention could be useful to be incorporated to the patients' treatment. In order to confirm or refute the effectiveness of this intervention, studies involving populations with these specific dysfunctions should be developed in the future.

\section{Conclusion}

The isokinetic knee extensors eccentric training was able to promote morphological gains in VM and VL muscles, with more pronounced changes for VM and neural gains only for the VM muscle. This behavior might be important in events where a different response between these muscles is expected, such as the regain in balance between them to prevent and/or treat knee joint dysfunctions, such as the patellofemoral pain syndrome.

\section{References}

American College of Sports Medicine (2009). American College of Sports Medicine position stand. Progression models in resistance training for healthy adults. Medicine and Science in Sports and Exercise, 41, 687-708.

Baroni, B.M., Geremia, J.M., Rodrigues, R., Franke, R.A., Karaminidis, K., \& Vaz, M.A. (2013a). Muscle architecture adaptations to knee extensor eccentric training: rectus femoris $v s$. vastus lateralis. Muscle and Nerve, 48, 498-506.

Baroni, B.M., Leal Junior, E.C., De Marchi, T., Lopes, A.L., Salvador, M., \& Vaz, M.A. (2010). Low level laser therapy before eccentric exercise reduces muscle damage markers in humans. European Journal of Applied Physiology, 110, 789-796.

Baroni, B.M., Rodrigues, R., Franke, R.A., Geremia, J.M., Rassier, D.E., \& Vaz, M.A. (2013b). Time course of neuromuscular adaptations to knee extensor eccentric training. International Journal of Sports Medicine, 34, 904-911.

Barroso, R., Tricoli, V., \& Ugrinowitsch, C. (2005) Adaptações neurais e morfológicas ao treinamento de força com ações excêntricas. Revista Brasileira de Ciência e Movimento, 13, 111-122.

Barstow, I.K., Bishop, M.D., \& Kaminski, T.W. (2003). Is enhanced-eccentric resistance training superior to traditional training for increasing elbow flexor strength? Journal of Sports Science and Medicine, 2, 62-69.

Blazevich, A.J., Cannavan, D., Coleman, D.R., \& Horne, S. (2007). Influence of concentric and eccentric resistance training on architectural adaptation in human quadriceps muscles. Journal of Applied Physiology, 103, 1565-1575.

Blazevich, A.J., Horne, S., Cannavan, D., Coleman, D.R., \& Aagaard, P. (2008). Effect of contraction mode of slow-speed resistance training on the maximum rate of force development in the human quadriceps. Muscle and Nerve, 38, 1133-1146.

Bojsen-Møller, J., Magnusson, S.P., Rasmussen, L.R., Kjaer, M., \& Aagaard, P. (2005). Muscle performance during maximal isometric and dynamic contractions is influenced by the stiffness of the tendinous structures. Journal of Applied Physiology, 99, 986-94.

Cerny, K. (1995). Vastus medialis oblique/vastus lateralis muscle activity ratios for selected exercises in persons with and without patellofemoral pain syndrome. Physical Therapy, 75, 672-683.

Clarkson, P.M., \& Hubal, M.J. (2002). Exercise-induced muscle damage in humans. American Journal of Physical Medicine and Rehabilitation, 81, 52-69.

Eapen, C., Nayak, C.D., \& Pazhyaottyil Zulfeequer, C. (2011). Effect of eccentric isotonic quadriceps muscle exercises on patellofemoral pain syndrome: an exploratory pilot study. Asian Journal of Sports Medicine, 2, 227-34.

Enoka, R.M. (1996). Eccentric contractions require unique activation strategies by the nervous system. Journal of Applied Physiology, 81, 2339-2346.

Folland, J.P., \& Williams, A.G. (2007). The adaptations to strength training: morphological and neurological contributions to increased strength. Sports Medicine, 37, 145-168.

Fridén, J., Lieber, R.L. (1998). Segmental muscle fiber lesions after repetitive eccentric contractions. Cell and Tissue Research, 293, 165-171.

Gerber, J.P., Marcus, R.L., Dibble, L.E., Greis, P.E., Burks, R.T., \& LaStayo, P.C. (2009). Effects of early progressive eccentric exercise on muscle size and function after anterior cruciate ligament reconstruction: A 1-year follow-up study of a randomized clinical trial. Physical Therapy, 89, 51-59.

Guilhem, G., Cornu, C., \& Guével, A. (2010). Neuromuscular and muscle-tendon system adaptations to isotonic and isokinetic eccentric exercise. Annals of Physical and Rehabilitation Medicine, 53, 319-341. 
Guilhem, G., Cornu, C., Maffiuletti, N.A., \& Guével, A. (2013). Neuromuscular adaptations to isoload versus isokinetic eccentric resistance training. Medicine and Science in Sports and Exercise, 45, 326-335.

Guilhem, G., Cornu, C., \& Guével, A. (2011). Muscle architecture and EMG activity changes during isotonic and isokinetic eccentric exercises. European Journal of Applied Physiology, 111, 2723-2733.

Hedayatpour, N., \& Falla, D. (2012). Non-uniform muscle adaptations to eccentric exercise and the implications for training and sport. Journal of Electromyography and Kinesiology 22, 329-333.

Higbie, E.J., Cureton, K.J., Warren, G.L. III, \& Prior, B.M. (1996). Effects of concentric and eccentric training on muscle strength, cross-sectional area, and neural activation. Journal of Applied Physiology, 81, 2173-2181.

Hortobagyi, T., Barrier, J., Beard, D., Braspennincx, J., Koens, P., Devita, P., ...Lambert, J. (1996a). Greater initial adaptations to submaximal muscle lengthening than maximal shortening. Journal of Applied Physiology, 81, 1677-1682.

Hortobagyi, T., Hill, J.P., Houmard, J.A., Fraser, D.D., Lambert, N.J., \& Israel, R.G. (1996b). Adaptive responses to muscle lengthening and shortening in humans. Journal of Applied Physiology, 80, 765-772.

Howatson, G., \& Someren, K.A.van (2008). The prevention and treatment of exercise-induced muscle damage. Sports Medicine, 38, 483-503.

Jonsson, P., \& Alfredson, H. (2005). Superior results with eccentric compared to concentric quadriceps training in patients with jumper's knee: a prospective randomised study. British Journal of Sports Medicine, 39, 847-850.

Kushion, D., Rheaume, J., Kopchitz, K., Glass, S., Alderink, G., \& Jann-Huei Jinn, J. H. (2012). EMG activation of the vastus medialis oblique and vastus lateralis during four rehabilitative exercises. The Open Rehabilitation Journal, 5, 1-7.

LaBella, C. (2004). Patellofemoral pain syndrome: evaluation and treatment. Primary Care: Clinics in Office Practice, 31, 977-1003.

Lorenz, D., \& Reiman, M. (2011). The role and implementation of eccentric training in athletic rehabilitation: tendinopathy, hamstring strains, and ACL reconstruction. International Journal of Sports and Physical Therapy, 6, 27-44.

Matheson, J.W., Kernozek, T.W., Fater, D.C.W., \& Davies, G.J. (2001). Electromyographic activity and applied load during seated quadriceps exercises. Medicine and Science in Sports and Exercise, 33, 1713-1725.

McNair, P.J., Depledge, J., Brettkelly, M., \& Stanley, S.N. (1996). Verbal encouragement: effects on maximum effort voluntary muscle action. British Journal of Sports Medicine, 30, 243-245.

Mirzabeigi, E., Jordan, C., Gronley, J.K., Rockowitz, N.L., \& Perry, J. (1999). Isolation of the vastus medialis oblique muscle during exercise. The American Journal of Sports Medicine, 27, 50-53.

Morgan, D.L., \& Proske, U. (2004). Popping sarcomere hypothesis explains stretch induced muscle damage. Proceedings of the Australian Physiological and Pharmacological Society, 34, 19-23.

Moritani, T., deVries, H.A. (1979). Neural factors versus hypertrophy in the time course of muscle strength gain. American Journal of Physical Medicine, 58, 115-130.

Narici, M.V., Hoppeller, H., Kayser, B., Landoni, L., Claassen, H., Gavardi, C., ...Cerretelli, P. (1996). Human quadriceps cross-sectional area, torque and neural activation during 6 months strength training. Acta Physiologica Scandinavica, 157, 175-186.

Narici, M.V., Roi, G.S., Landoni, L., Minetti, A.E., \& Cerretelli, P. (1989). Changes in force, cross-sectional area and neural activation during strength training and detraining of the human quadríceps. European Journal of Applied Physiology and Occupational Physiology, 58, 310-319.
Neptune, R.R., Wright, I.C., \& Van Den Bogert, A.J. (2000). The influence of orthotic devices and vastus medialis strength and timing on patellofemoral loads during running. Clinical Biomechanics, $15,611-618$.

Norrbrand, L., Fluckey, J.D., Pozzo, M., \& Tesch, P.A. (2008). Resistance training using eccentric overload induces early adaptations in skeletal muscle size. European Journal of Applied Physiology, 102, 271-281.

Peng, H.T., Kernozek, T.W., \& Song, C.Y. (2013). Muscle activation of vastus medialis obliquus and vastus lateralis during a dynamic leg press exercise with and without isometric hip adduction. Physical Therapy in Sports, 14, 44-49.

Powers, C.M., Landel, R., \& Perry, J. (1996). Timing and intensity of vastus muscle activity during functional activities in participants with and without patellofemoral pain. Physical Therapy, 76, 946-955.

Raj, I.S., Bird, S.R., Westfold, B.A., \& Shield, A.J. (2012). Effects of eccentrically biased versus conventional weight training in older adults. Medicine Science in Sports and Exercise, 44, 1167-1176.

Reeves, N.D., Maganaris, C.N., Longo, S., \& Narici, M.V. (2009). Differential adaptations to eccentric versus conventional resistance training in older humans. Experimental Physiology, 94, 825-833.

Rocha, C.S.S., Baroni, B.M., Lanferdini, F.J., Freitas, C.R., Frasson, V.B., \& Vaz, M.A. (2011). Specificity of strength gains after 12 weeks of isokinetic eccentric training in healthy men. Isokinetics and Exercise Science, 19, 221-226.

Roig, M., O’Brien, K., Kirk, G., Murray, R., McKinnon, P., Shadgan, B., \& Reid, W.D. (2009). The effects of eccentric versus concentric resistance training on muscle strength and mass in healthy adults: a systematic review with meta-analysis. British Journal of Sports Medicine, 43, 556-568.

Schoenfeld, B.J. (2010). The mechanisms of muscle hypertrophy and their application to resistance training. Journal of Strength and Conditioning Research, 24, 2857-2872.

Sczepanski, T.L., Gross, M.T., Duncan, P.W., \& Chandler, J.M. (1991). Effect of contraction type, angular velocity, and arc of motion on VMO:VL EMG ratio. Journal of Orthopaedic and Sports Physical Therapy, 14, 256-262.

SENIAM (2013). Surface ElectroMyoGraphy for the Non-Invasive Assessment of Muscles. Retrieved December 5, 2013, from: http:// www.seniam.org.

Serrão, F.V., Cabral, C.M.N., Bérzin, F., Candolo, C., \& Monteiro-Pedro, V. (2005). Effect of tibia rotation on the electromyographical activity of the vastus medialis oblique and vastus lateralis longus muscles during isometric leg press. Physical Therapy in Sport, 6, 15-23.

Seynnes, O.R., Boer, M., \& Narici, M.V. (2007). Early skeletal muscle hypertrophy and architectural changes in response to high-intensity resistance training. Journal of Applied Physiology, 102, 368-373.

Sheehy, P., Burdett, R.G., Irrgang, J.J., \& VanSwearingen, J. (1998). An electromyographic study of vastus medialis oblique and vastus lateralis activity while ascending and descending steps. Journal of Orthopaedic and Sports Physical Therapy, 27, 423-429.

Sole, G., Hamrén, J., Milosavljevic, S., Nicholson, H., \& Sullivan, S.J. (2007). Test-Retest Reliability of Isokinetic Knee Extension and Flexion. Archives of Physical Medicine and Rehabilitation, $88,626-631$.

Takekura, H., Fujinami, N., Nishizawa, T., Ogasawara, H., \& Kasuga, N. (2001). Eccentric exercise-induced morphological changes in the membrane systems involved in excitation-contraction coupling in rat skeletal muscle. Journal of Physiology, 533, 571-583.

Travnik, L., Pernus, F., \& Erzen, I. (1995). Histochemical and morphometric characteristics of the normal human vastus medialis longus and vastus medialis oblique muscles. Journal of Anatomy, $187,403-411$. 
Vikne, H., Refsnes, P.E., Ekmark, M., Medbø, J.I., Gundersen, V., \& Gundersen, K. (2006). Muscular performance after concentric and eccentric exercise in trained men. Medicine and Science in Sports and Exercise, 38, 1770-1781.

Visnes, H., \& Bahr, R. (2007). The evolution of eccentric training as treatment for patellar tendinopathy (jumper's knee): a critical review of exercise programmes. British Journal of Sports Medicine, 41, 217-223.

Ward, S.R., Eng, C.M., Smallwood, L.H., \& Lieber, R.L. (2009). Are current measurements of lower extremity muscle architecture accurate? Clinical Orthopaedics and Related Research, 467, 1074-1082.

Webber, S., \& Kriellaars, D. (1997). Neuromuscular factors contributing to in vivo eccentric moment generation. Journal of Applied Physiology, 83, 40-45.

Wernbom, M., Augustsson, J., \& Thomee, R. (2007). The influence of frequency, intensity, volume and mode of strength training on whole muscle cross-sectional area in humans. Sports Medicine, 37, 225-264.

Wong, Y.M., Chan, S.T., Tang, K.W., \& Ng, G.Y.F. (2009). Two Modes of Weight Training Programs and Patellar Stabilization. Journal of Athletic Training, 44, 264-271.

Wong, Y.M., \& Ng, G.Y.F. (2010). Resistance training alters the sensorimotor control of vasti muscles. Journal of Electromyography and Kinesiology, 20, 180-184.

\section{Authors' note}

Rodrigo de Azevedo Franke is a master's student, and is affiliated with the Exercise Research Laboratory, School of Physical Education, Federal University of Rio Grande do Sul, Porto Alegre, Rio Grande do Sul, Brazil.

Jeam Marcel Geremia, Rodrigo Rodrigues and Fábio Juner Lanferdini are doctoral students, and are affiliated with the Exercise Research Laboratory, School of Physical Education, Federal University of Rio Grande do Sul, Porto Alegre, Rio Grande do Sul, Brazil.

Bruno Manfredini Baroni, $\mathrm{PhD}$, is a professor at the Federal University of Health Sciences of Porto Alegre, Porto Alegre, Rio Grande do Sul, Brazil.

Marco Aurélio Vaz, $\mathrm{PhD}$, is a professor and is affiliated with the Exercise Research Laboratory, School of Physical Education, Federal University of Rio Grande do Sul, Porto Alegre, Rio Grande do Sul, Brazil.

\section{Additional information}

This study is part of the doctoral thesis of Bruno Manfredini Baroni and was presented in the 2013 International Congress of Physical Activity and Human Movement Sciences (VIII CIEFMH - XIV SPEF), awarded as "best paper" presented in the conference's area of Exercise physiology and biodynamic aspects of sport training and performance.

\section{Acknowledgements}

The authors would like to thank Coordenação de Aperfeiçoamento de Pessoal de Nível Superior (CAPES-Brazil) and Conselho Nacional de Pesquisa (CNPq-Brazil) for financial support and all volunteers for their participation in this project.

\section{Corresponding author}

Rodrigo de Azevedo Franke Exercise Research Laboratory (LAPEX) Federal University of Rio Grande do Sul (UFRGS)

Rua Felizardo, 750 - Bairro Jardim Botânico, Porto Alegre 90690-200, RS, Brazil

Phone: 55-51-33085894

E-mail: rodrigo_franke@hotmail.com

Manuscript received on February 13, 2014

Manuscript accepted on May 13, 2014

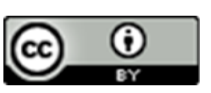

Motriz. The Journal of Physical Education. UNESP. Rio Claro, SP, Brazil - eISSN: 1980-6574 - under a license Creative Commons - Version 3.0 